\title{
Perspective
}

\section{The coronavirus pandemic: a pitfall or a fast-track for validating cell therapy products?}

Maroun Khoury ${ }^{1,2}$, Laertis Ikonomou ${ }^{3}$, Massimo Dominici ${ }^{4}$, Katarina LeBlanc ${ }^{5}$, Bruce L. Levine $^{6}$ and Daniel J. Weiss ${ }^{7 *}$

${ }^{1}$ Laboratory of Nano-Regenerative Medicine, Faculty of Medicine, Universidad de los Andes, Santiago, Chile.

${ }^{2}$ Cells for Cells and Consorcio Regenero, Chilean Consortium for Regenerative Medicine, Santiago, Chile

3 Department of Oral Biology, University at Buffalo, The State University of New York, Buffalo, NY, USA.

4 Department of Medical and Surgical Sciences for Children and Adults, Division of Oncology, University Hospital of Modena, Italy.

5 Department of Laboratory Medicine, Karolinska Institutet, CAST, Patient Area Cell Therapies and Allogeneic Stem Cell Transplantation, Karolinska University Hospital, Stockholm, Sweden.

${ }^{6}$ Center for Cellular Immunotherapies, Department of Pathology and Laboratory Medicine, and Abramson Cancer Center, Perelman School of Medicine, University of Pennsylvania, Philadelphia, Pennsylvania, USA.

${ }^{7}$ Department of Medicine, University of Vermont, Burlington, VT, USA

*To whom correspondence may be addressed:

Daniel J. Weiss, MD, PHD

Department of Medicine,

University of Vermont,

Burlington, VT USA

Phone: $+1802-847-1158$

E-mail: daniel.weiss@med.uvm.edu 
Abstract:

The global COVID-19 pandemic has prompted urgent need for potential therapies for severe respiratory consequences resulting from coronavirus infection. New therapeutic agents that will attenuate ongoing inflammation and at the same time promote regeneration of injured lung epithelial cells are urgently needed. Cell-based therapies, primarily involving mesenchymal stromal cells (MSCs) and their derivatives are currently being investigated worldwide for SARS-CoV-2-induced lung diseases. A significant number of academic centers and companies globally have already initiated such trials. However, at a time of unprecedented need, it is also foreseen that families and caregivers will seek all available options including access to cell-based and other investigational products, even prior to proven safety and efficacy as well as regulatory approval. This should not be an excuse for opportunists to sell or advertise unproven therapies of any kind. "Compassionate use" should be conducted in the context of a clinical investigation framed by strict ethical and regulatory permissions, with the goal of obtaining mechanistic information wherever possible. 

develop effective therapies that can lessen disease severity in infected patients, particularly those with severe respiratory disease. Cell-based approaches, primarily using mesenchymal stromal cells (MSCs), have demonstrated an acceptable safety profile in patients with non-SARS-CoV-2 related acute respiratory distress syndrome (ARDS) in the limited currently available information. ${ }^{1}$ However, whether these therapies are effective for treating respiratory virus-induced ARDS, including that resulting from SARS-CoV-2, is unknown.[1] This is despite several recent case reports and uncontrolled case series suggesting potential efficacy.[2,3] Regardless, there are an increasing number of both academic and industry-sponsored trials of cell-based therapies for COVID-19 patients initiated over the past several months. Most are investigating use of MSCs, but some are investigating MSC-derived products including extracellular vesicles (EVs) and some are utilizing other cell types. In parallel, there has been a worrisome increase in the number of businesses offering unproven and untested cell-based therapy approaches in uncontrolled and unregulated settings.[4] This creates a potentially dangerous situation for patients, families, and care-givers in often desperate situations.

An overview of the rationale, pre-clinical data, and clinical experience of cell-based therapy in non-COVID-related ARDS provides a strong platform underlying legitimate investigations. There is a wealth of pre-clinical data in both small and large animal models as well as in explanted human lungs in which either systemic or direct airway administration of MSCs mitigates experimentally-induced acute lung injuries resulting from bacteria or bacterial product, for example gram-negative bacterial endotoxin, administration.[5,6] The postulated mechanisms largely focus on paracrine actions of the administered MSCs including release of anti-inflammatory cytokines, anti-bacterial peptides, and extracellular vesicles that mitigate inflammation in the setting of acute lung injuries (Figure 1).[7] These encouraging results have provided a basis for the growing number of academic and industry-sponsored investigations of systemically administered MSCs in (non-COVID) ARDS patients.[1] While these studies have uniformly demonstrated a good safety profile, there remains uncertainty about potential efficacy. One major academic-based trial did not demonstrate clinical efficacy[8], whereas improvement in clinically relevant endpoints including increased ventilator-free and ICU-free days and 
decreased one month mortality, was suggested in one major industry trial.[9] However, neither of these trials have specifically targeted patients with respiratory virus-induced ARDS. Further, there are only a small number of pre-clinical studies in models of respiratory virus infection and these all involve influenza rather than coronavirus. Notably, there were contrasting results of efficacy in these studies, possibly related to the type of influenza (swine vs. avian) infection utilized. This furthers adds to uncertainty about whether MSC or other cell or cell product administration will have specific efficacy in SARSCoV-2 induced respiratory failure. There is almost no available clinical data with respect to MSC administration in other types of respiratory virus infections with only a case report in a patient with H1N1 flu-related ARDS (allogeneic bone marrow-derived MSCs)[10] and a case series following H7N9 flu infection (allogeneic menstrual blood-derived MSCs).[11]

A recent search (November, 2020) of the NIH clinical trial database and the World Health Organization-International Clinical Trial Registry Platform (WHO-ICTRP) revealed over 3,787 recently registered clinical trials for COVID-19. Among these are 154 cell and gene therapy-based trials worldwide, with most registered in China (41) and the the USA (36). Most of these utilize MSCs or their secreted products, including EVs or conditioned media. In a previous comprehensive review, we had presented an exhaustive summary of ongoing studies registered in the Chinese Clinical Trial Registry (chictr.org.cn) also accessible from the World Health Organization-International Clinical Trial Registry Platform (WHOICTRP).[1] Following the continued spread of the pandemic, we complement that information with an updated list of trials with investigational new drug (IND) clearance from the US.FDA (Table 1). Notably, a wide range of protocols with allogeneic MSCs of different origins, different doses, and different dosing strategies are being utilized. The dose of injected cells ranges from 0.5 to $2 \times 10^{6}$ cells $/ \mathrm{kg}$ or the equivalent in a predefined infusion dose. The number of injections varies between a single dose and up to three doses separated between 3- 5 days with one trial utilizing up to 4 separate doses. . Importantly, there is also a wide range of patient groups being targeted including those with mild or moderate disease in addition to those with severe disease. A variety of enrollment designs are being utilized including emergency and compassionate use, with only a small proportion of trials using a randomized, double-blinded placebo control format. Also, the use of autologous MSC derived from the patient's adipose tissue is used 
in 3 registered trials. It is unclear whether the cells were obtained previous to infection through adult stem cell banking or harvested after infection. In two trials, MSC are being used as prophylaxis not only in asymptomatic COVID-19 patients but also in healthy individuals at high or very high exposure risk of contracting COVID-19. While the majority of investigations are utilizing modified MSCs, one industry trial is evaluating the safety and feasibility of MSCs RNA-engineered to secrete a combination of DNases (Table 1). Further, although there is a less robust mechanistic and pre-clinical platform, at least seven investigations are utilizing other cell types including, among others, cytotoxic T cells (CTL), dendritic cells (DC), primary natural killer cells (NK) and induced pluripotent stem cell (iPSC)-derived NK cells already being used to treat cancer patients [12]. There is a paucity of direct evidence for the protective or pathological role of NK cells in the response to SARS-Cov-2 infection. In the context of non-respiratory viral infections by human immunodeficiency virus (HIV) and hepatitis C virus (HCV), NK cells appear to prevent T cellmediated autoimmunity through their cytotoxic properties [13]. However, NK cells are one of the main producers of the pro-inflammatory mediator IFN- $\gamma$, hence, they may be involved in the induction or perpetuation of inflammation-mediated lung injuries, and subsequent mortality associated with COVID-19 [14]

Despite the lack of preclinical information in COVID-19 or any other respiratory virus pathophysiology, there has been clearance by the FDA of an investigational new drug (IND) application for the use of NK cells in clinical testing. [15] Whether these approaches are even safe for COVID-19 patients has yet to be clarified. As such we urge the FDA and other regulatory agencies to take a careful position with respect to approving cell-based products with unclear track records in either pre-clinical or clinical studies in lung diseases or critical illnesses for use in COVID 19 patients.

Convalescent T-cells isolated from COVID-19 patients are also being considered. Recently, SARS-CoV-2 -specific T-cells were shown to be polyfunctional and can be expanded from convalescent individuals. These T-cell were able to target structural viral proteins, including the C-terminus of membrane protein, making them good candidate for the prevention or early treatment of SARS-CoV-2 infection in immunocompromised patients with blood disorders [16]. 
Of the recent published reports and small case series from both academic and industry sources suggesting potential efficacy of systemic MSC administration in COVID-19 patients, the available data presented is either anecdotal or from incompletely presented, poorly controlled investigations.[2,17] The situation is also further complicated by lack of consensus or full understanding with respect to MSC source of origin, dose, dosing strategy, use of freshly thawed vs. continuously cultured cells, and other factors involved in potential use of MSC-based cell therapies. The same holds for a recent published initial safety investigation utilizing MSC-derived EVs in which no information about the actual biological substance being administered was provided.[18] Therefore, while there may be a potential role for MSCs and other cell-based therapies in treatment of COVID-19, these need to be investigated in a rationally designed, controlled approach if safety and efficacy are to be demonstrated accurately. Importantly, in addition to legitimate peer-reviewed academic trials being conducted globally, one industry-sponsored prospective randomized, double blinded, placebo-controlled phase II ( intramuscular injection of Placental-MSC, ClinicalTrials.gov Identifiers: NCT04389450) and two phase III trials of intravenously administered marrow-derived MSC-like products for severe COVID-19 have been initiated in the USA (NCT04367077 and NCT04371393). The hope is these and comparable studies will provide robust data informing the utility of systemic MSC administration for COVIDrelated ARDS (Table 1).

At a time of unprecedented need, it is natural for patients, families, and caregivers to seek all available options including access to cell-based and other investigational products, even prior to adequate demonstration of safety and efficacy and according regulatory approval. This should not be an excuse for opportunists to sell or advertise unproven therapies of any kind. "Compassionate use" should be conducted in the context of a clinical investigation framed by strict ethical and regulatory permissions, such as expanded access authorization, with the goal of obtaining mechanistic information wherever possible. There must be a strong stance against the rogue stem-cell clinic industry which has already begun to offer unproven therapies for COVID-19. A number of global organizations, including the International Society for Cell and Gene Therapy (ISCT) and the International Society for Stem Cell Research (ISSCR), have taken positions against this predatory behavior.[19] The FDA has recently increased oversight activities against businesses 
offering unproven therapies, but more regulatory oversight and action are needed.[20] These actions are necessary to develop rationale evidence-based platform for potential use of cell-based therapies both for COVID-19 but also for a wider range of respiratory and other diseases potentially amenable to these advanced therapies.

\section{Author Disclosure Statement}

Maroun Khoury PHD is assistant professor at the faculty of medicine of the University of los Andes, Santiago, Chile and Chief Scientific Officer of Cells for Cells and Regenero (Chile), spin-offs of the same University. He receives research support from the Chilean National Agency for Research and Development (ANID), the Economic Development Agency of the Chilean Government (CORFO), Cells for Cells-Regenero and from the University of Los Andes.

Laertis Ikonomou PhD is Associate Professor of Oral Biology at the University at Buffalo, The State University of New York and the Chair of the International Society for Cell \& Gene Therapy Presidential Task Force (PTF) on the Use of Unproven and/or Unethical Cell and Gene Therapy. He has written an expert report in a class action lawsuit filed against a business selling unproven stem cell interventions and wrote the report on a pro bono basis.

Massimo Dominici, MD is Professor of Oncology at the University of Modena, Italy. He is a specialist physician at the Department of Medical and Surgical Sciences for Children and Adults, University Hospital of Modena, Italy. He receives research support from Associazione Italiana Ricerca Cancro (AIRC), the Associazione Sostegno Ematologia e Oncologia Pediatrica (ASEOP), the Associazione ASLEM and MIUR (Progetto Dipartimenti Eccellenti 2017). He has been chair of the ISCT Presidential Task Force on Unproven cell and gene therapy (2014-2020).

Katarina LeBlanc, MD PHD is Professor of Clinical Stem Cell Research at the Division of Clinical Immunology and Transfusion Medicine, Karolinska Institutet and Senior Consultant, Center of Allogeneic Stem Cell Transplantation and Cellular Therapy (CAST), Karolinska University Hospital Huddinge, Stockholm, Sweden. She receives research 
support from the Swedish Research Council, Stockholm County Council, Swedish Foundation for Strategic Research, Laryngfonden, Karolinska Institutet.

Bruce L. Levine is the Barbara and Edward Netter Professor of Cancer Gene Therapy at the Perelman School of Medicine at the University of Pennsylvania and President of the International Society for Cell and Gene Therapy. Disclosures of equity: Tmunity Therapeutics. Honoraria: Novartis, Terumo, AstraZeneca. Consulting or Advisory Role: Brammer Bio/ThermoFisher Viral Vector Services, Avectas, Immuneel, Ori Biotech, Vycellix.

Daniel J. Weiss MD PhD is Professor of Medicine at the University of Vermont and Chief Scientific Officer of the International Society for Cell \& Gene Therapy. He receives research support from the National Institutes of Health, Department of Defense, Cystic Fibrosis Foundation, and the University of Vermont. He has written an expert report in a class action lawsuit filed against a business selling unproven stem cell interventions and wrote the report on a pro bono basis. 


\section{References}

1. Khoury M, J Cuenca, FF Cruz, FE Figueroa, PRM Rocco and DJ Weiss (2020). Current status of cell-based therapies for respiratory virus infections: applicability to COVID-19. Eur Respir J 55: 2000858.

2. Leng Z, R Zhu, W Hou, Y Feng, Y Yang, Q Han, G Shan, F Meng, D Du, S Wang, J Fan, W Wang, L Deng, H Shi, H Li, Z Hu, F Zhang, J Gao, H Liu, X Li, Y Zhao, K Yin, X He, Z Gao, Y Wang, B Yang, R Jin, I Stambler, LW Lim, H Su, A Moskalev, A Cano, S Chakrabarti, KJ Min, G Ellison-Hughes, C Caruso, K Jin and RC Zhao (2020). Transplantation of ACE2- Mesenchymal stem cells improves the outcome of patients with covid-19 pneumonia. Aging Dis 11: 216228.

3. Sánchez-Guijo F, M García-Arranz, M López-Parra, P Monedero, C Mata-Martínez, A Santos, V Sagredo, JM Álvarez-Avello, JE Guerrero, C Pérez-Calvo, MV Sánchez-Hernández, JL Del-Pozo, EJ Andreu, ME Fernández-Santos, B Soria-Juan, LM Hernández-Blasco, E Andreu, JM Sempere, AG Zapata, JM Moraleda, B Soria, F Fernández-Avilés, D García-Olmo and F Prósper (2020). Adipose-derived mesenchymal stromal cells for the treatment of patients with severe SARS-CoV-2 pneumonia requiring mechanical ventilation. A proof of concept study. EClinicalMedicine 25:.

4. Turner L (2020). Preying on Public Fears and Anxieties in a Pandemic: Businesses Selling Unproven and Unlicensed "Stem Cell Treatments" for COVID-19. Cell Stem Cell 26: 806810.

5. Cruz FF, DJ Weiss and PRM Rocco (2016). Prospects and progress in cell therapy for acute respiratory distress syndrome. Expert Opin Biol Ther 16: 1353-1360.

6. McIntyre LA, D Moher, DA Fergusson, KJ Sullivan, SHJ Mei, M Lalu, J Marshall, M McLeod, G Griffin, J Grimshaw, A Turgeon, MT Avey, MA Rudnicki, M Jazi, J Fishman and DJ Stewart (2016). Efficacy of mesenchymal stromal cell therapy for acute lung injury in preclinical animal models: A systematic review. PLoS One 11: e0147170.

7. Laffey JG and MA Matthay (2017). Cell-based therapy for acute respiratory distress syndrome: Biology and potential therapeutic value. Am J Respir Crit Care Med 196: 266273. 
8. Matthay MA, CS Calfee, H Zhuo, BT Thompson, JG Wilson, JE Levitt, AJ Rogers, JE Gotts, JP Wiener-Kronish, EK Bajwa, MP Donahoe, BJ McVerry, LA Ortiz, M Exline, JW Christman, J Abbott, KL Delucchi, L Caballero, M McMillan, DH McKenna and KD Liu (2019). Treatment with allogeneic mesenchymal stromal cells for moderate to severe acute respiratory distress syndrome (START study): a randomised phase 2a safety trial. Lancet Respir Med 7: 154-162.

9. Athersys Provides Update on One-Year ARDS Study Data.

10. Simonson OE, D Mougiakakos, $N$ Heldring, G Bassi, HJ Johansson, M Dalén, R Jitschin, $S$ Rodin, M Corbascio, S El Andaloussi, OPB Wiklander, JZ Nordin, J Skog, C Romain, T Koestler, L Hellgren-Johansson, P Schiller, P-O Joachimsson, H Hägglund, M Mattsson, J Lehtiö, OR Faridani, R Sandberg, O Korsgren, M Krampera, DJ Weiss, K-H Grinnemo and K Le Blanc (2015). In Vivo Effects of Mesenchymal Stromal Cells in Two Patients With Severe Acute Respiratory Distress Syndrome. Stem Cells Transl Med 4: 1199-1213.

11. Chen J, C Hu, L Chen, L Tang, Y Zhu, X Xu, L Chen, H Gao, X Lu, L Yu, X Dai, C Xiang and L Li (2020). Clinical Study of Mesenchymal Stem Cell Treatment for Acute Respiratory Distress Syndrome Induced by Epidemic Influenza A (H7N9) Infection: A Hint for COVID-19 Treatment. Engineering.

12. University of Minnesota expands clinical investigation of engineered iPSC-derived natural killer cells, opening U.S. clinical trial for the treatment of COVID-19 | University of Minnesota.

13. Jost S and M Altfeld (2013). Control of Human Viral Infections by Natural Killer Cells. Annu Rev Immunol 31: 163-194.

14. Market M, L Angka, AB Martel, D Bastin, O Olanubi, G Tennakoon, DM Boucher, J Ng, M Ardolino and RC Auer (2020). Flattening the COVID-19 Curve With Natural Killer Cell Based Immunotherapies. Front Immunol 11: 1512.

15. BRIEF-Celularity Announces FDA Clearance Of IND Application For CYNK-001 In Coronavirus, First In Cellular Therapy - Reuters.

16. Keller MD, KM Harris, MA Jensen-Wachspress, V Kankate, H Lang, CA Lazarski, JR Durkee-Shock, P-H Lee, K Chaudhry, K Webber, A Datar, M Terpilowski, EK Reynolds, E Stevenson, S Val, Z Shancer, N Zhang, R Ulrey, U-O Ekanem, M Stanojevic, AE Geiger, H Liang, F Hoq, AA Abraham, PJ Hanley, CRY Cruz, K Ferrer, L Dropulic, K Gangler, PD Burbelo, 
RB Jones, JI Cohen and CM Bollard (2020). SARS-CoV-2 specific T-cells Are Rapidly

Expanded for Therapeutic Use and Target Conserved Regions of Membrane Protein. Blood. 17. Shu L, C Niu, R Li, T Huang, Y Wang, M Huang, N Ji, Y Zheng, X Chen, L Shi, M Wu, K Deng, J Wei, X Wang, Y Cao, J Yan and G Feng (2020). Treatment of severe COVID-19 with human umbilical cord mesenchymal stem cells. Stem Cell Res Ther 11: 361.

18. Sengupta V, S Sengupta, A Lazo, P Woods, A Nolan and N Bremer (2020). Exosomes Derived from Bone Marrow Mesenchymal Stem Cells as Treatment for Severe COVID-19. Stem Cells Dev 29: 747-754.

19. Ikonomou L (2020). Cell-based treatments for COVID-19. 27:.

20. Khoury M, PRM Rocco, DG Phinney, M Krampera, I Martin, S Viswanathan, JA Nolta, K LeBlanc, J Galipeau and DJ Weiss (2020). Cell-Based Therapies for COVID-19: Proper Clinical Investigations are Essential. Cytotherapy 22: 602-605. 


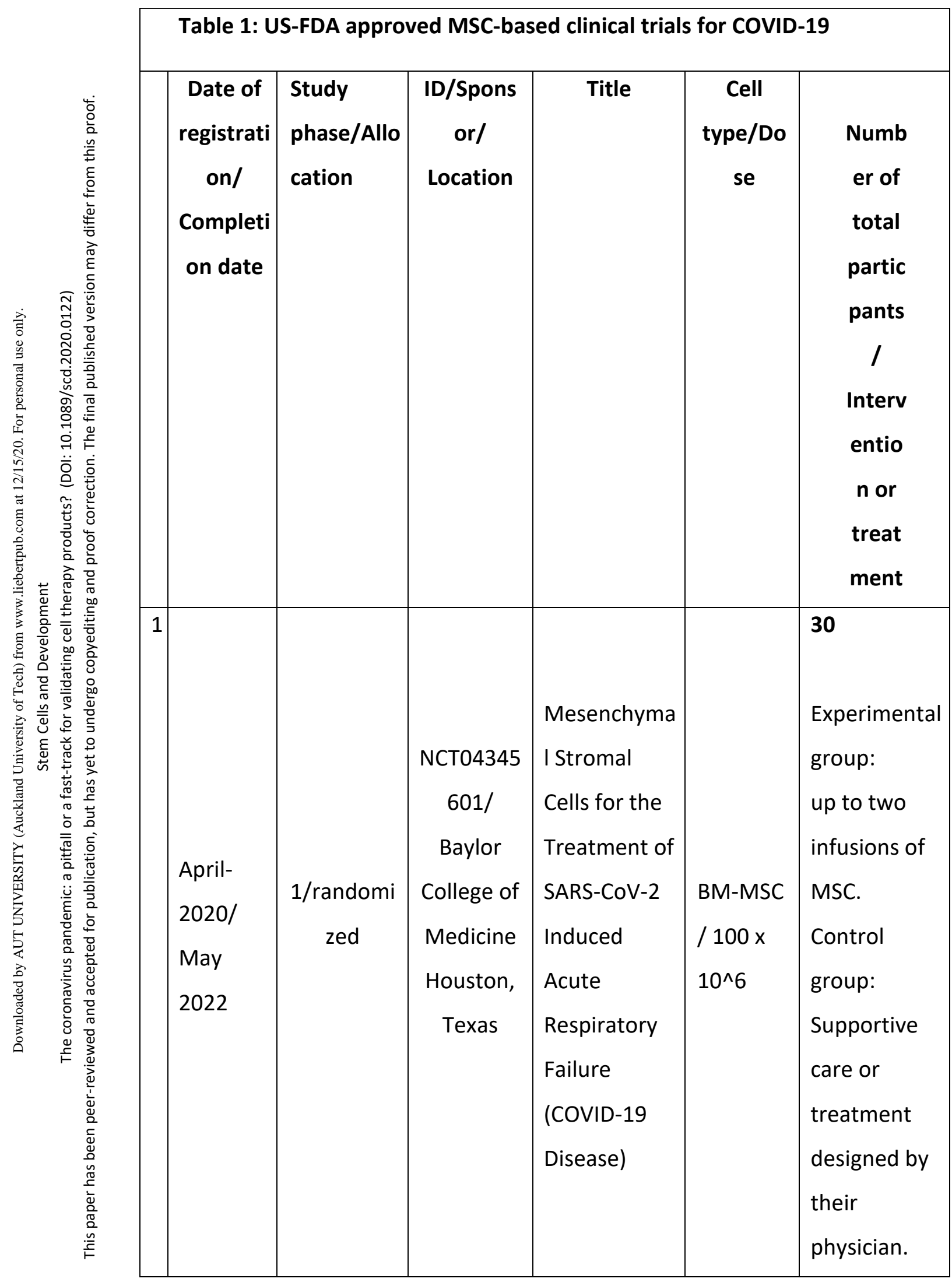




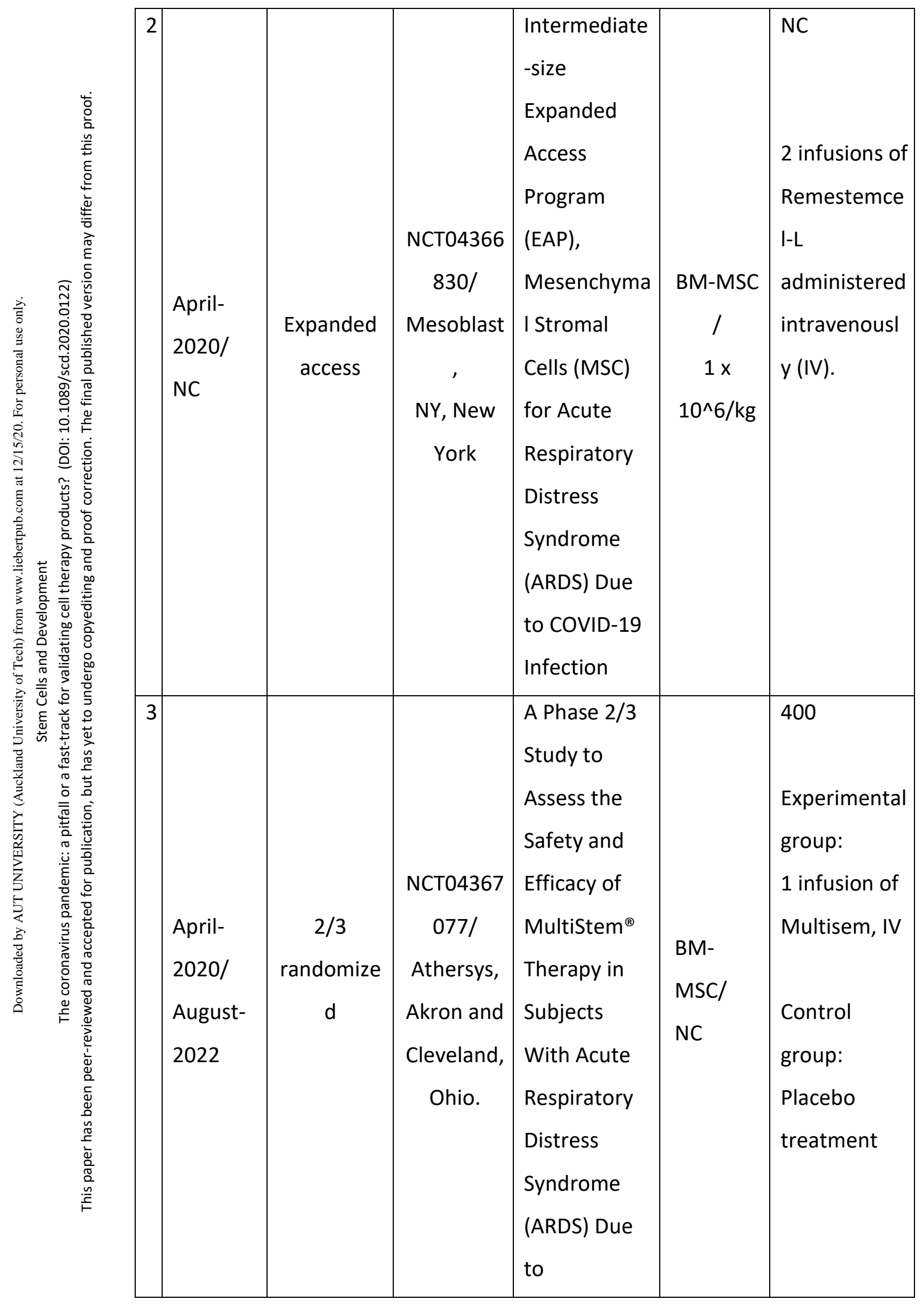




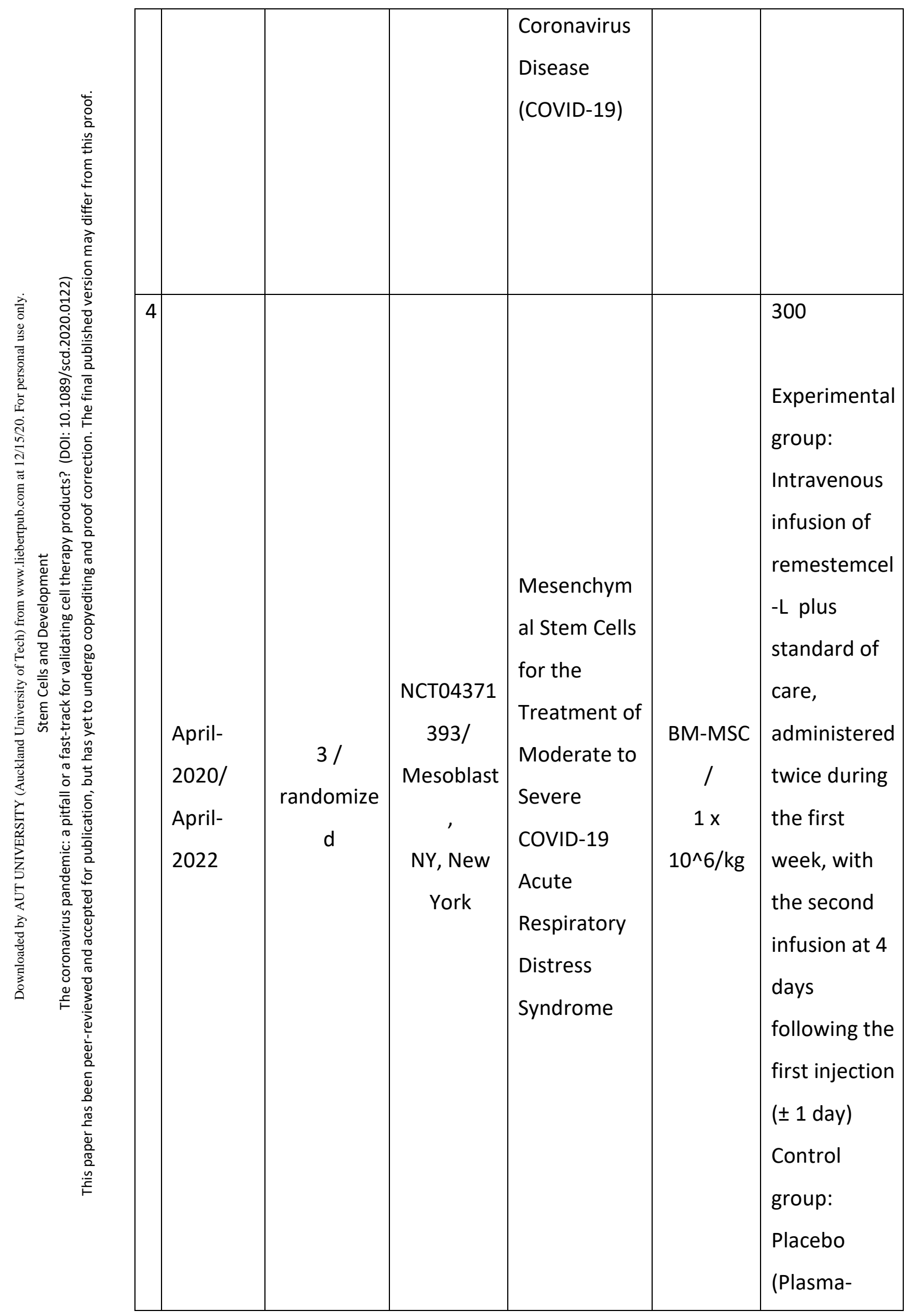




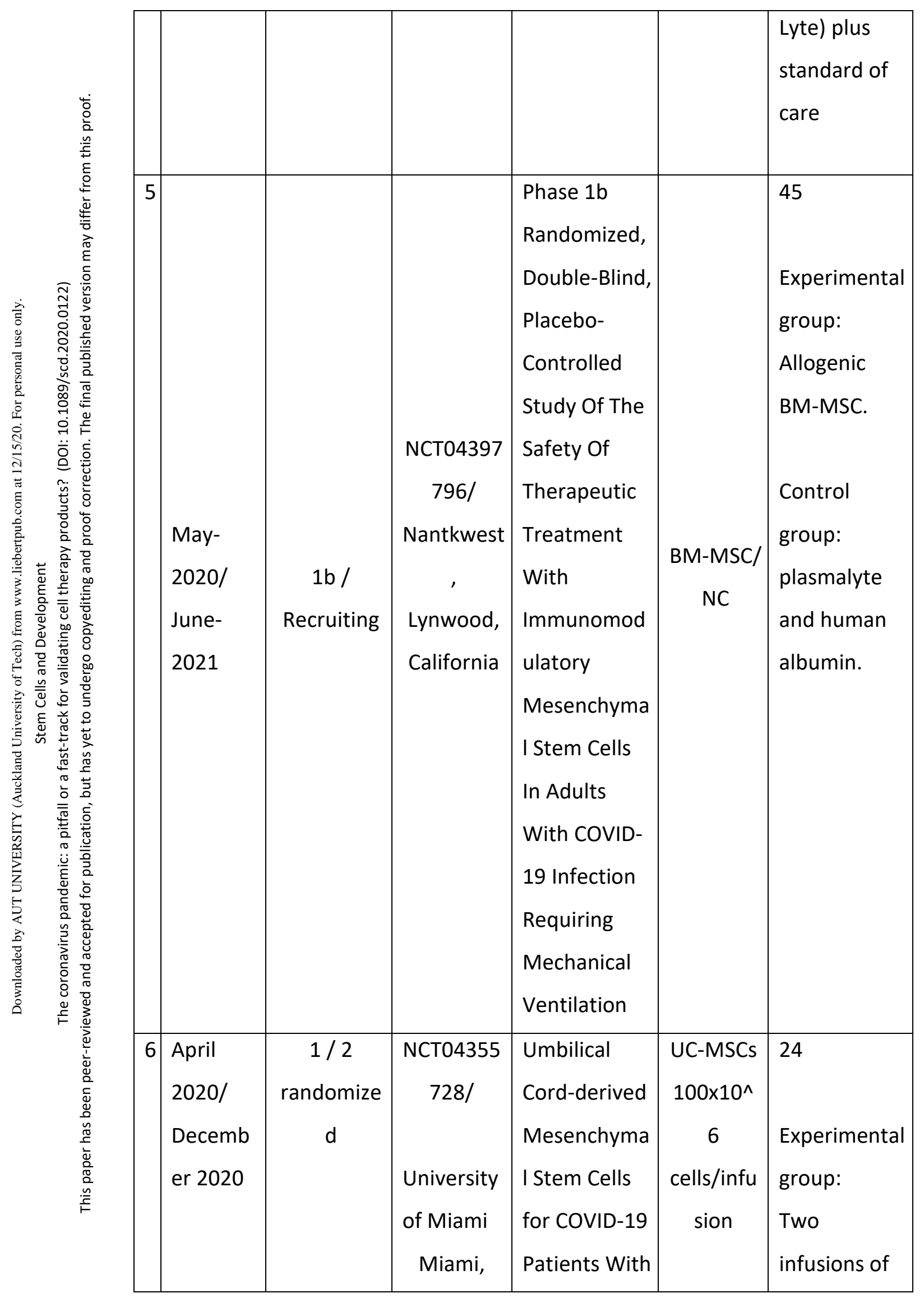


Page 16 of 30

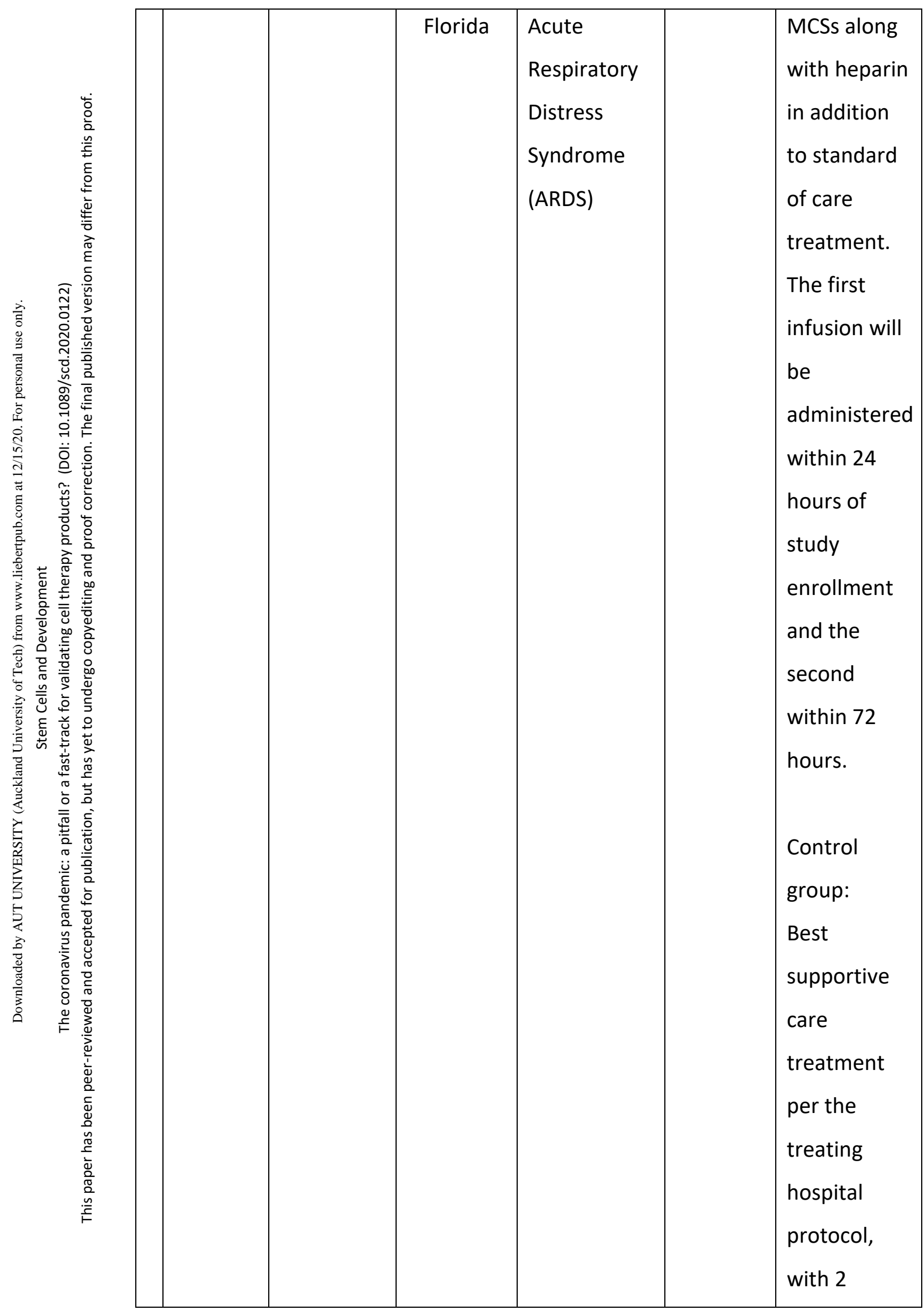




\begin{tabular}{|c|c|c|c|c|c|c|c|}
\hline 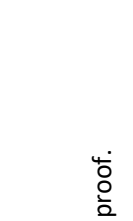 & & & & & & \multicolumn{2}{|c|}{$\begin{array}{l}\text { infusion of } \\
\text { vehicle + } \\
\text { heparin. }\end{array}$} \\
\hline 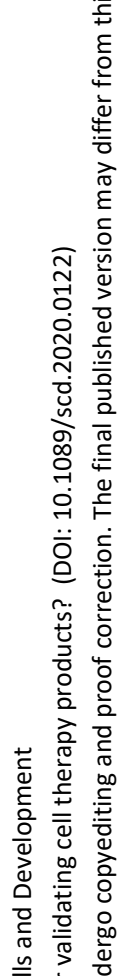 & 7 & $\begin{array}{l}\text { June- } \\
\text { 2020/ } \\
\text { July-2021 }\end{array}$ & $\begin{array}{l}1 / 2 \\
\text { randomiz } \\
\text { ed }\end{array}$ & $\begin{array}{c}\text { NCT04399889/ } \\
\text { Duke } \\
\text { University, } \\
\text { Durham, North } \\
\text { Carolina }\end{array}$ & $\begin{array}{l}\text { Pilot Study of } \\
\text { Safety and } \\
\text { Efficacy of Cord } \\
\text { Tissue Derived } \\
\text { Mesenchymal } \\
\text { Stromal Cells } \\
\text { (hCT-MSC) in } \\
\text { COVID-19 } \\
\text { Related Acute } \\
\text { Respiratory } \\
\text { Distress } \\
\text { Syndrome } \\
\text { (ARDS) }\end{array}$ & $\begin{array}{l}\text { UC-MSCs/ } \\
\text { NC }\end{array}$ & $\begin{array}{l}30 \\
\text { Experimenta } \\
\text { I group: } \\
\text { UC-MSC } \\
\text { Control } \\
\text { group: } \\
\text { Standard of } \\
\text { care }\end{array}$ \\
\hline 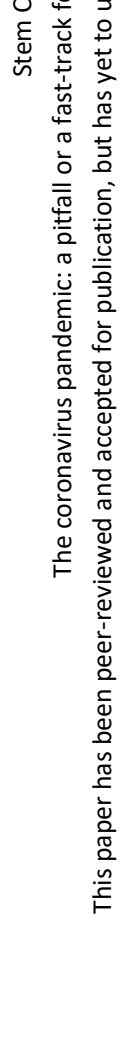 & 8 & $\begin{array}{l}\text { June- } \\
2020 / \\
\text { June- } \\
2021\end{array}$ & $\begin{array}{l}1 \text { / not- } \\
\text { randomiz } \\
\text { ed }\end{array}$ & $\begin{array}{c}\text { NCT04452097/ } \\
\text { Baylx, } \\
\text { Irvine, } \\
\text { California }\end{array}$ & $\begin{array}{l}\text { A Phase } 1 \\
\text { Study of the } \\
\text { Safety and } \\
\text { Tolerability of } \\
\text { BX-U001 for } \\
\text { the Treatment } \\
\text { of Severe } \\
\text { COVID-19 } \\
\text { Pneumonia } \\
\text { With Moderate } \\
\text { to Severe } \\
\text { Acute } \\
\text { Respiratory } \\
\text { Distress }\end{array}$ & $\begin{array}{c}\text { UC- } \\
\text { MSCs } \\
0,5 \text { or } 1 \text { or } \\
1,5 x \\
10^{\wedge} 6 / \mathrm{kg}\end{array}$ & $\begin{array}{l}9 \\
\text { Experimenta } \\
\text { I group: } \\
\text { Low, } \\
\text { medium, } \\
\text { high dose, } \\
\text { Single } \\
\text { injection of } \\
\text { MSCs. }\end{array}$ \\
\hline
\end{tabular}




\begin{tabular}{|c|c|c|c|c|c|c|c|}
\hline & & & & & $\begin{array}{l}\text { Syndrome } \\
\text { (ARDS). }\end{array}$ & & \\
\hline 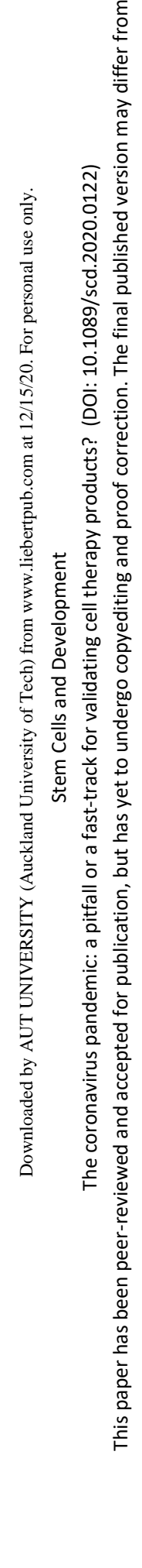 & 9 & $\begin{array}{l}\text { June- } \\
2020 / \\
\text { July- } \\
2024\end{array}$ & $\begin{array}{c}1 / 2 \\
\text { randomiz } \\
\text { ed }\end{array}$ & $\begin{array}{c}\text { NCT04490486/ } \\
\text { University of } \\
\text { Miami } \\
\text { Miami, Florida }\end{array}$ & $\begin{array}{l}\text { Phase I, } \\
\text { Randomized, } \\
\text { Double } \\
\text { Blinded, } \\
\text { Placebo } \\
\text { Control Study } \\
\text { to Evaluate the } \\
\text { Safety and } \\
\text { Potential } \\
\text { Efficacy of } \\
\text { Intravenous } \\
\text { Infusion of } \\
\text { Umbilical Cord } \\
\text { Tissue (UC) } \\
\text { Derived } \\
\text { Mesenchymal } \\
\text { Stem Cells } \\
\text { (MSCs) Versus } \\
\text { Placebo to } \\
\text { Treat Acute } \\
\text { Pulmonary } \\
\text { Inflammation } \\
\text { Due to CoVID- } \\
\text { 19 With } \\
\text { Moderate to } \\
\text { Symptoms }\end{array}$ & $\begin{array}{c}\text { UC-MSCs/ } \\
100 \times 10^{\wedge} 6 \\
\text { cells/infusi } \\
\text { on }\end{array}$ & $\begin{array}{l}21 \\
\text { Expe } \\
\text { rime } \\
\text { ntal } \\
\text { grou } \\
\text { p: } \\
\text { Two } \\
\text { intra } \\
\text { veno } \\
\text { us } \\
\text { (IV) } \\
\text { UCM } \\
\text { SCs } \\
\text { inter } \\
\text { venti } \\
\text { on } \\
\text { on } \\
\text { day } \\
0 \\
\text { and } \\
\text { day } \\
\text { group: }\end{array}$ \\
\hline
\end{tabular}


19

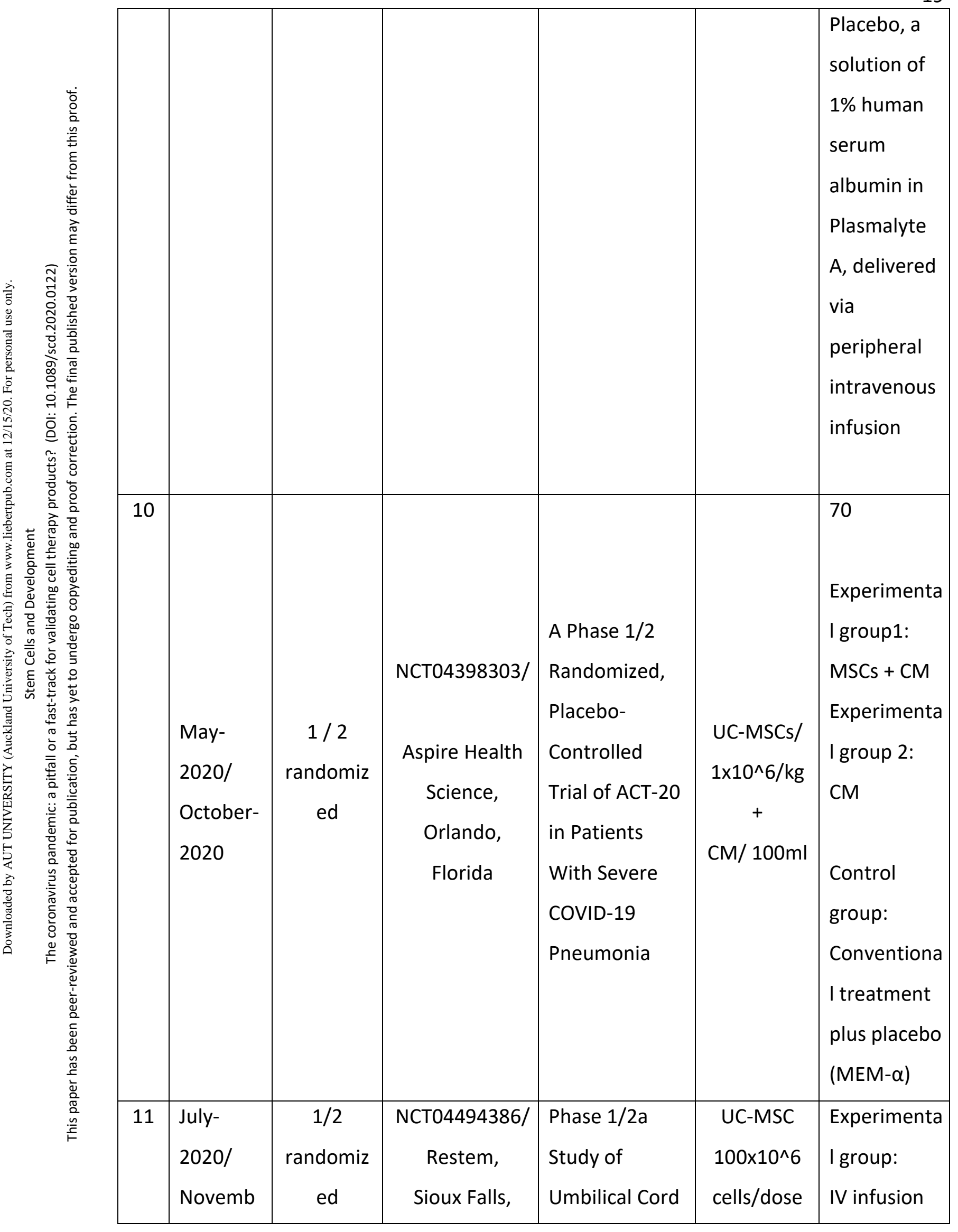


20

\begin{tabular}{|c|c|c|c|c|c|c|c|}
\hline 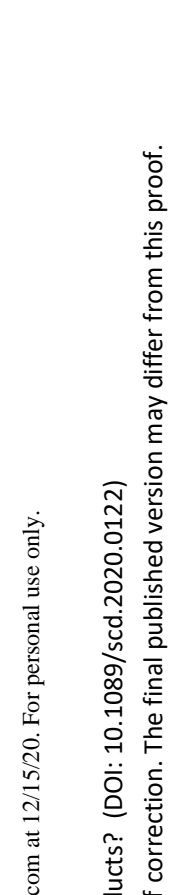 & & er-2021 & & South Dakota & $\begin{array}{l}\text { Lining Stem } \\
\text { Cells (ULSC) in } \\
\text { Patients With } \\
\text { ARDS Due to } \\
\text { COVID-19 }\end{array}$ & & $\begin{array}{l}\text { of MSC in } \\
\text { sterile saline } \\
\text { for injection } \\
\text { Control } \\
\text { group: } \\
\text { IV infusion } \\
\text { of carrier } \\
\text { control } \\
\text { consisting of } \\
\text { sterile saline } \\
\text { for injection }\end{array}$ \\
\hline 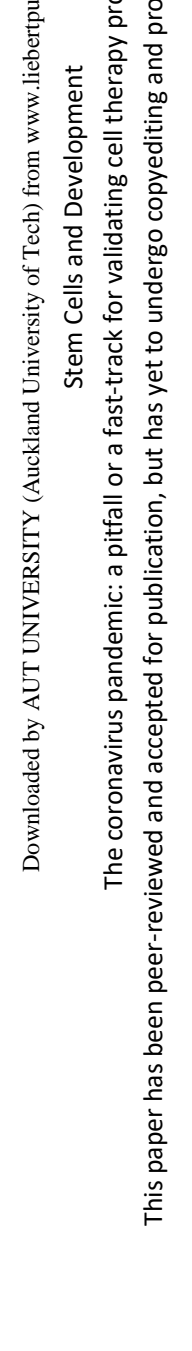 & 12 & $\begin{array}{l}\text { April- } \\
2020 / \\
\text { April- } \\
2021\end{array}$ & $\begin{array}{c}2 / \\
\text { randomiz } \\
\text { ed } \\
\text { (healthy } \\
\text { prophilaxi } \\
\text { s) }\end{array}$ & $\begin{array}{c}\text { NCT04348435/ } \\
\text { Hope } \\
\text { Biosciences } \\
\text { Sugar Land, } \\
\text { Texas }\end{array}$ & $\begin{array}{l}\text { A Randomized, } \\
\text { Double-Blind, } \\
\text { Single Center, } \\
\text { Efficacy and } \\
\text { Safety Study of } \\
\text { Allogeneic HB- } \\
\text { adMSCs to } \\
\text { Provide } \\
\text { Immune } \\
\text { Support } \\
\text { Against COVID- } \\
19\end{array}$ & $\begin{array}{c}\text { Adipose- } \\
\text { MSCs } \\
50,100 \text { or } \\
200 \\
\times 10^{\wedge} 6 / \text { dos } \\
e\end{array}$ & $\begin{array}{l}100 \\
\text { Experimenta } \\
\text { I group1: } \\
5 \\
\text { intravenous } \\
\text { infusions of } \\
\text { HB-adMSCs } \\
\text { at 200 } \\
\text { million } \\
\text { cells/dose. } \\
\text { Infusions } \\
\text { will occur at } \\
\text { weeks 0, 2, } \\
6,10 \text {, and } \\
\text { 14. } \\
\text { Experimenta } \\
\text { I group2: }\end{array}$ \\
\hline
\end{tabular}


21

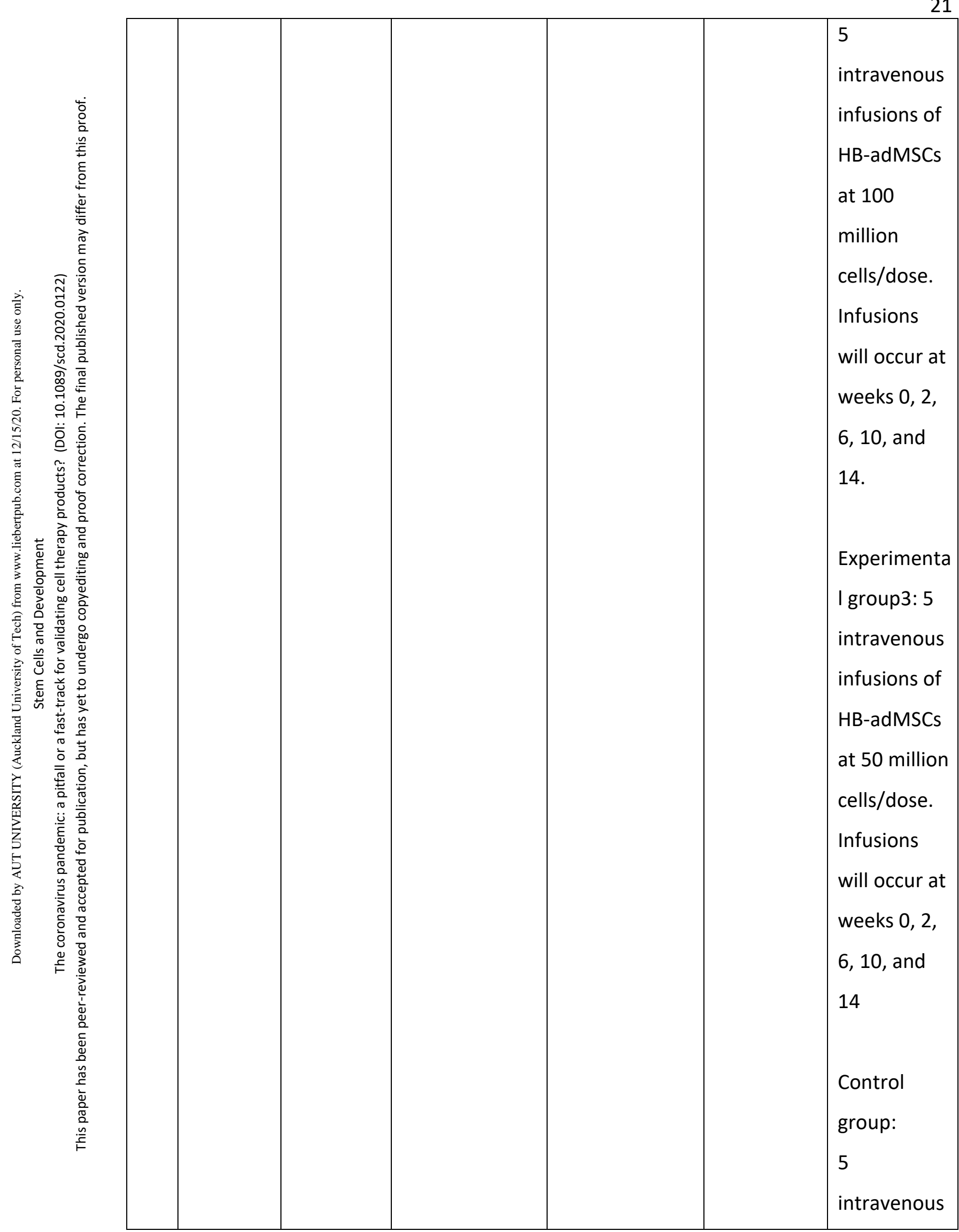




\begin{tabular}{|c|c|c|c|c|c|c|}
\hline & & & & & & $\begin{array}{l}\text { infusions of } \\
\text { placebo } \\
\text { intervention } \\
\text { (saline). } \\
\text { Infusions } \\
\text { will occur at } \\
\text { weeks } 0,2 \text {, } \\
6,10 \text {, and } \\
14 \text {. }\end{array}$ \\
\hline 13 & $\begin{array}{l}\text { April- } \\
\text { 2020/ } \\
\text { Decemb } \\
\text { er-2020 }\end{array}$ & $\begin{array}{c}\text { 2/ NC } \\
\text { (infected } \\
\text { prophilaxi } \\
\text { s) }\end{array}$ & $\begin{array}{c}\text { NCT0434963/ } \\
\text { Hope } \\
\text { Biosciences } \\
\text { Sugar Land, } \\
\text { Texas }\end{array}$ & $\begin{array}{l}\text { A Phase II, } \\
\text { Open Label, } \\
\text { Single-Center, } \\
\text { Clinical Trial to } \\
\text { Assess Efficacy } \\
\text { of HB-adMSCs } \\
\text { to Provide } \\
\text { Immune } \\
\text { Support } \\
\text { Against } \\
\text { Coronavirus } \\
\text { Disease }\end{array}$ & $\begin{array}{c}\text { Adipose- } \\
\text { MSCs/ } \\
\text { NC }\end{array}$ & $\begin{array}{l}56 \\
\text { Experimenta } \\
\text { I group: } \\
\text { Five IV } \\
\text { infusions of } \\
\text { autologous, } \\
\text { adipose- } \\
\text { derived } \\
\text { mesenchym } \\
\text { al stem } \\
\text { cells. }\end{array}$ \\
\hline 14 & $\begin{array}{l}\text { April- } \\
2020 / \\
\text { April- } \\
2026\end{array}$ & $\begin{array}{l}1 \text { / Non- } \\
\text { randomiz } \\
\text { ed }\end{array}$ & $\begin{array}{c}\text { NCT04352803/ } \\
\text { Regeneris } \\
\text { Medical, } \\
\text { North } \\
\text { Attleborough, } \\
\text { MA, }\end{array}$ & $\begin{array}{l}\text { IV Infusion of } \\
\text { Autologous } \\
\text { Adipose } \\
\text { Derived } \\
\text { Mesenchymal } \\
\text { Cells for } \\
\text { Abatement of } \\
\text { Respiratory } \\
\text { Compromise in }\end{array}$ & $\begin{array}{c}\text { Adipose- } \\
\text { MSCs } \\
0,5 \\
\times 10^{\wedge} 6 / \mathrm{kg}\end{array}$ & $\begin{array}{l}\text { Experimenta } \\
\text { I group: } \\
\text { Conventiona } \\
\text { I treatment } \\
\text { plus MSC. } \\
\text { Control }\end{array}$ \\
\hline
\end{tabular}




\begin{tabular}{|c|c|c|c|c|c|c|c|}
\hline 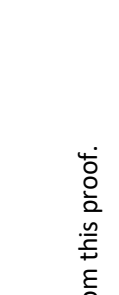 & & & & & $\begin{array}{l}\text { SARS-CoV-2 } \\
\text { Pandemic } \\
\text { (COVID-19 }\end{array}$ & & $\begin{array}{l}\text { group: } \\
\text { Conventiona } \\
\text { I treatment } \\
\text { only }\end{array}$ \\
\hline 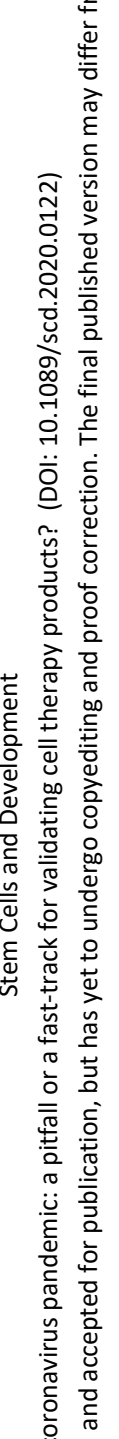 & 15 & $\begin{array}{l}\text { April- } \\
2020 / \\
\text { October- } \\
2020\end{array}$ & $\begin{array}{c}2 / \\
\text { randomiz } \\
\text { ed }\end{array}$ & $\begin{array}{c}\text { NCT04362189/ } \\
\text { Hope } \\
\text { Biosciences } \\
\text { Houston, Texas }\end{array}$ & $\begin{array}{l}\text { A Randomized, } \\
\text { Placebo- } \\
\text { Controlled, } \\
\text { Double-Blind, } \\
\text { Efficacy and } \\
\text { Safety Study of } \\
\text { Allogeneic HB- } \\
\text { adMSCs for } \\
\text { the Treatment } \\
\text { of COVID-19 }\end{array}$ & $\begin{array}{c}\text { Adipose- } \\
\text { MSCs } \\
100 \times 10^{\wedge} 6 \\
\text { cells/infusi } \\
\text { on }\end{array}$ & $\begin{array}{l}100 \\
\text { Experimenta } \\
\text { I group: } \\
4 \\
\text { intravenous } \\
\text { infusions of } \\
\text { MSC at day } \\
0,3,7, \text { and } \\
\text { 10. } \\
\text { Control } \\
\text { group: } 4 \\
\text { intravenous } \\
\text { infusions of } \\
\text { placebo } \\
\text { (saline } \\
\text { solution) at } \\
\text { day } 0,3,7, \\
\text { and } 10 .\end{array}$ \\
\hline 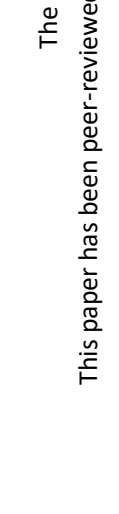 & 16 & $\begin{array}{l}\text { June- } \\
2020 / \\
\text { January } \\
2022\end{array}$ & $\begin{array}{c}2 / \\
\text { randomize } \\
\text { d }\end{array}$ & $\begin{array}{c}\text { NCT04428801 } \\
\text { Celltex } \\
\text { Therapeutics } \\
\text { Corporation, } \\
\text { Houston, } \\
\text { Texas }\end{array}$ & $\begin{array}{l}\text { Clinical } \\
\text { Study for the } \\
\text { Prophylactic } \\
\text { Efficacy of } \\
\text { Autologous } \\
\text { Adipose } \\
\text { Tissue- }\end{array}$ & $\begin{array}{c}\text { Adipose- } \\
\text { MSCs } \\
200 \times 10^{\wedge} 6 \\
\text { cells/infusio } \\
n\end{array}$ & $\begin{array}{l}\text { Experimental } \\
\text { group: } \\
\text { Three doses } \\
\text { of autologous } \\
\text { adipose }\end{array}$ \\
\hline
\end{tabular}


24

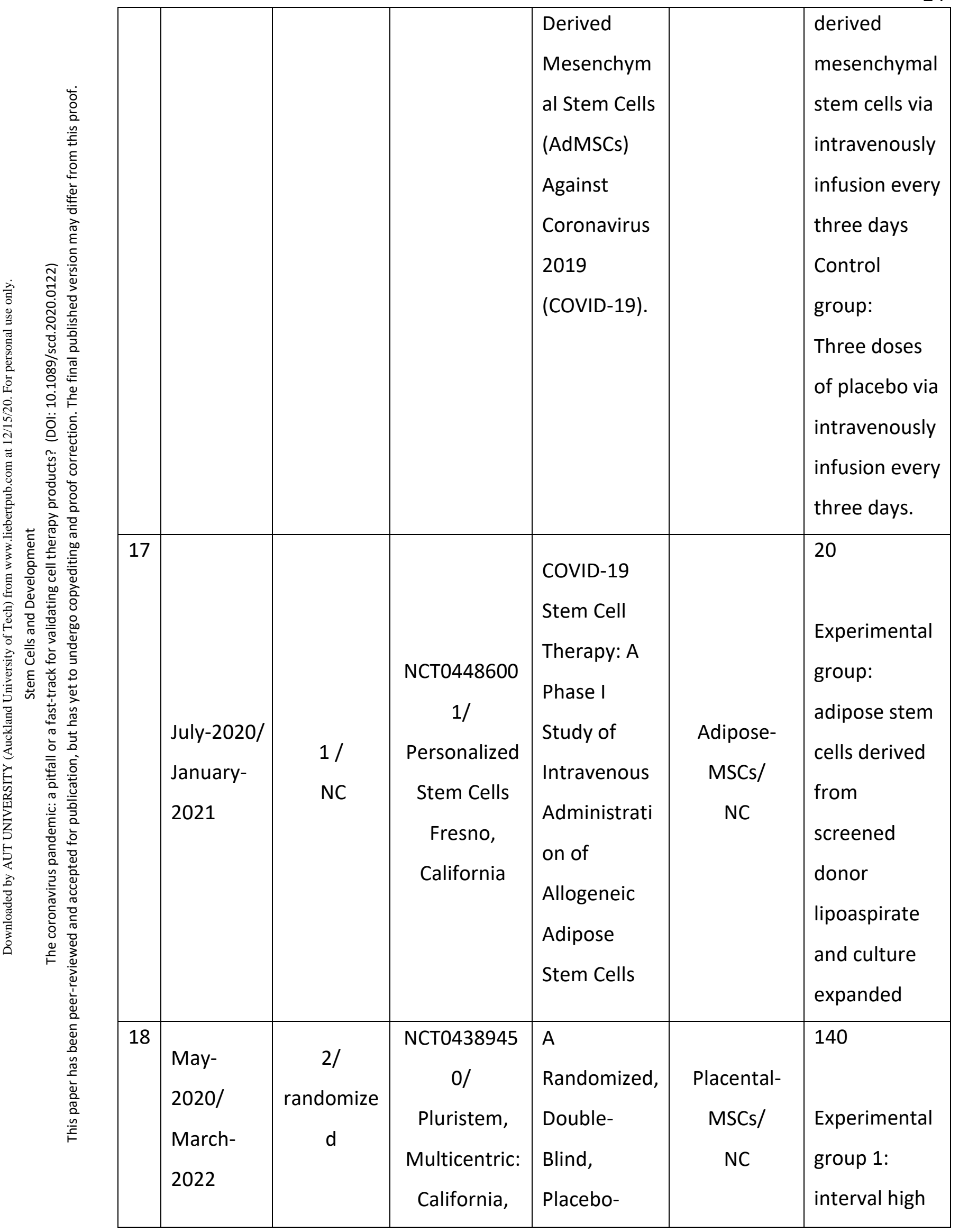




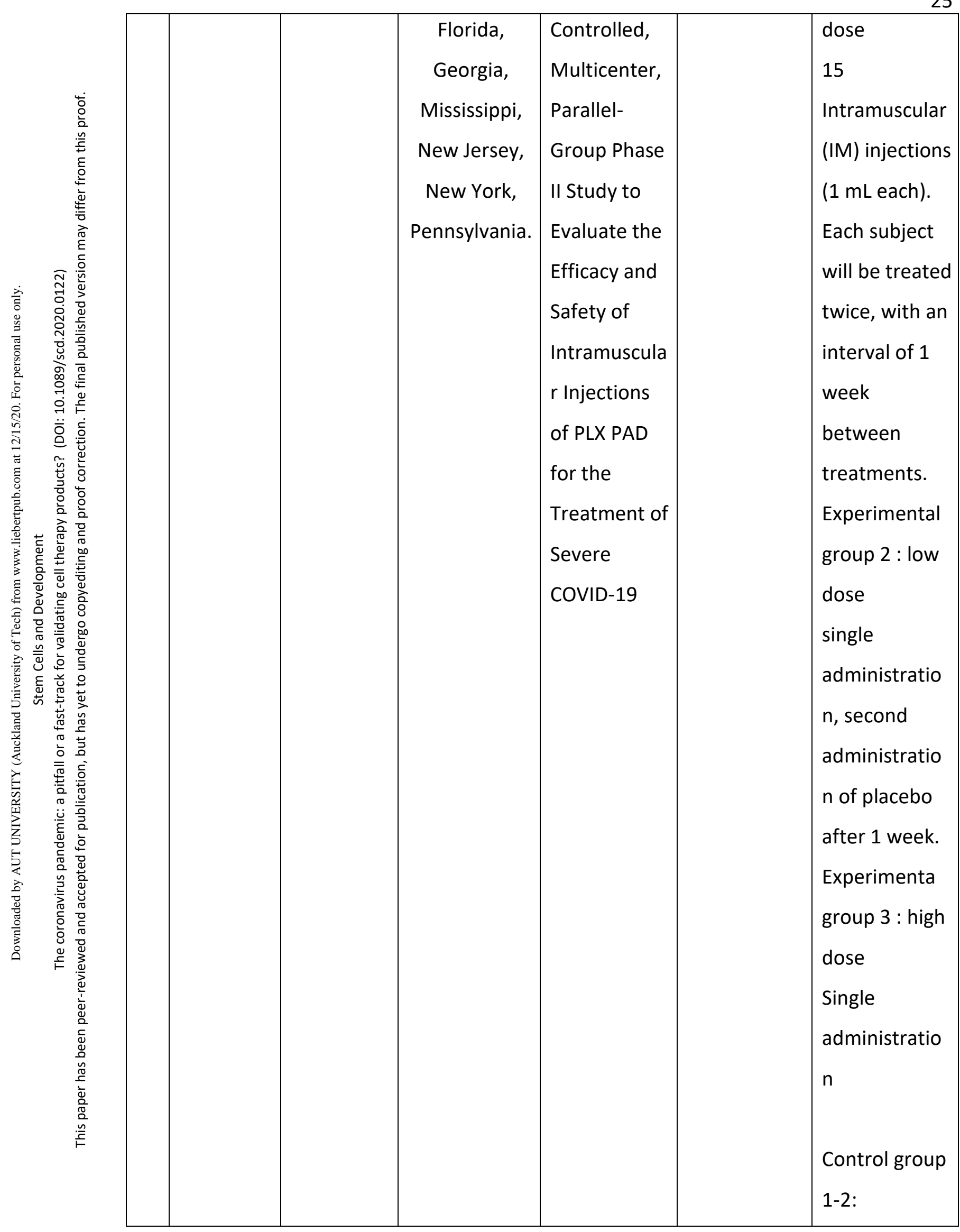


26

\begin{tabular}{|c|c|c|c|c|c|c|c|}
\hline 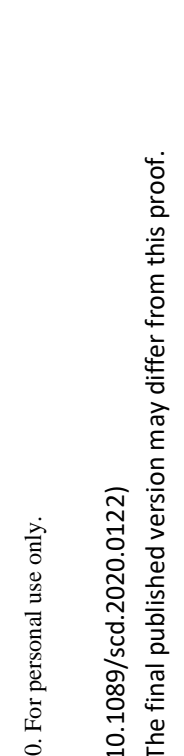 & & & & & & & $\begin{array}{l}\text { Placebo, two } \\
\text { administratio } \\
\text { ns, } 1 \text { week } \\
\text { apart. } \\
\text { Control group } \\
\text { 3: } \\
\text { Placebo, } \\
\text { single } \\
\text { administratio } \\
\text { n/ }\end{array}$ \\
\hline 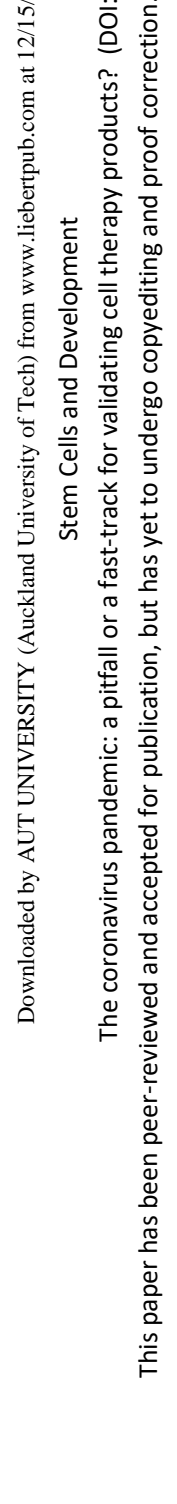 & 19 & $\begin{array}{l}\text { Septembe } \\
\text { r-2020/ } \\
\text { April-2021 }\end{array}$ & $\begin{array}{c}1 / \\
\text { randomize } \\
\text { d }\end{array}$ & $\begin{array}{c}\text { NCT0456566 } \\
\text { 5/ } \\
\text { M.D. } \\
\text { Anderson } \\
\text { Cancer } \\
\text { Center, } \\
\text { Houston, } \\
\text { Texas }\end{array}$ & $\begin{array}{l}\text { Emergency } \\
\text { Use Pilot } \\
\text { Study of } \\
\text { Cord Blood } \\
\text { Derived } \\
\text { Mesenchyma } \\
\text { I Stem Cells } \\
\text { for } \\
\text { Treatment of } \\
\text { CoviD-19 } \\
\text { Related } \\
\text { Acute } \\
\text { Respiratory } \\
\text { Distress } \\
\text { Syndrome }\end{array}$ & 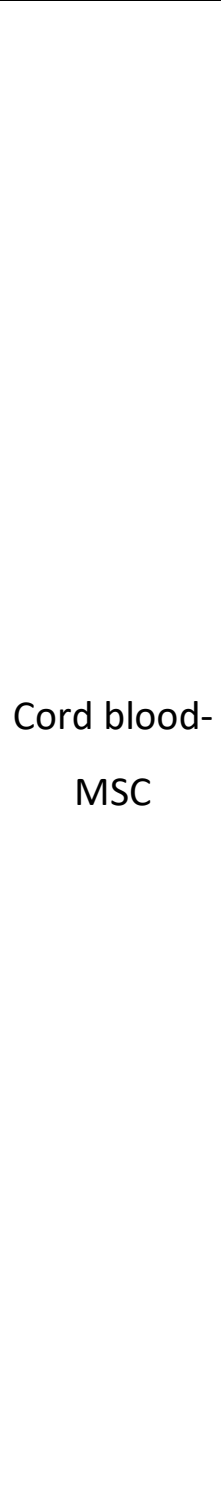 & $\begin{array}{l}70 \\
\text { Experimental: } \\
\text { Pilot study } \\
\text { Patients } \\
\text { receive MSCs } \\
\text { IV over 1-2 } \\
\text { hours on day } \\
\text { 1. Patients } \\
\text { may receive a } \\
\text { second } \\
\text { infusion of } \\
\text { MSCs within } 7 \\
\text { days after the } \\
\text { first infusion } \\
\text { per physician } \\
\text { discretion } \\
\text { Experimental: } \\
\text { Phase II Arm I } \\
\text { Patients }\end{array}$ \\
\hline
\end{tabular}


27

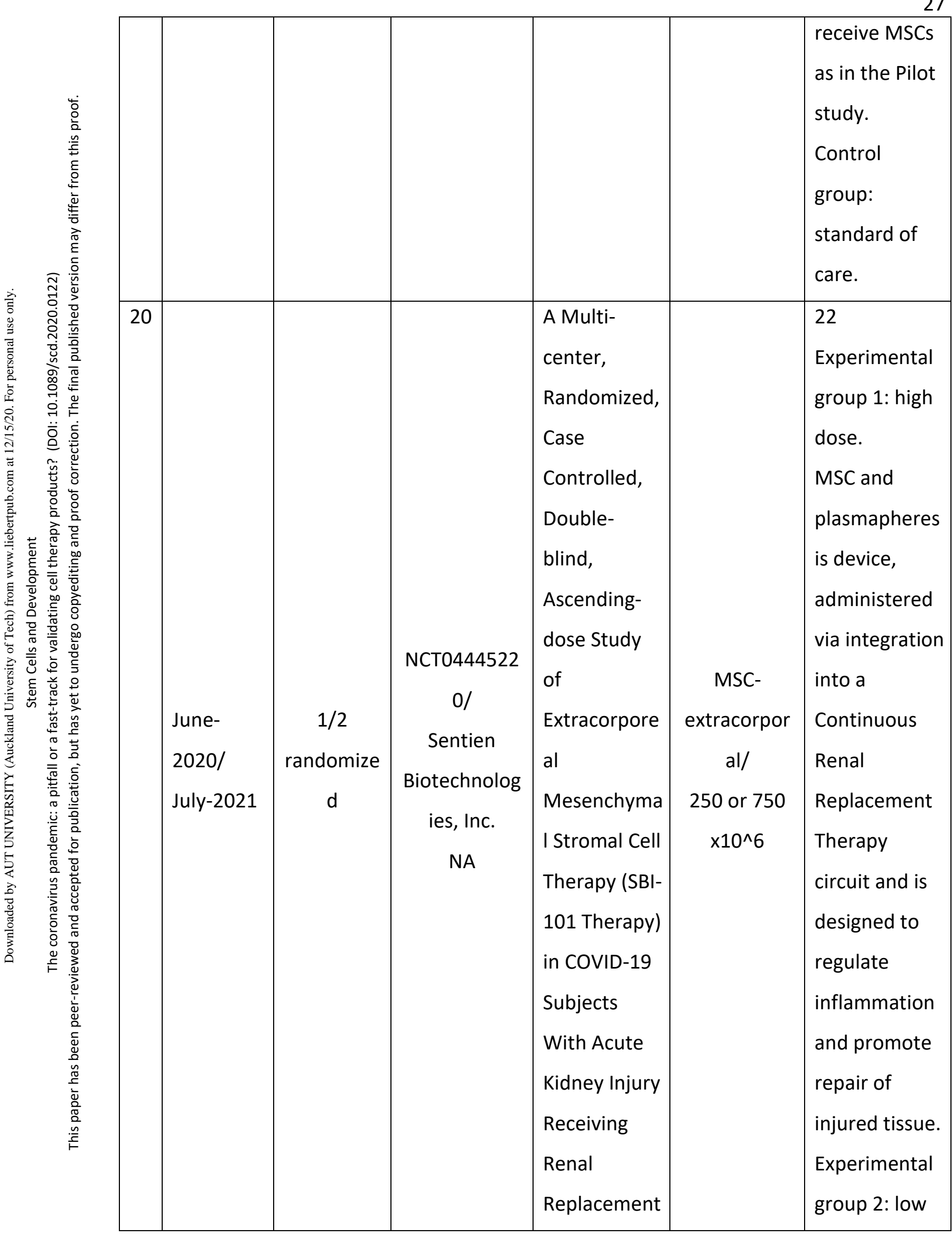




\begin{tabular}{|c|c|c|c|c|c|c|c|}
\hline 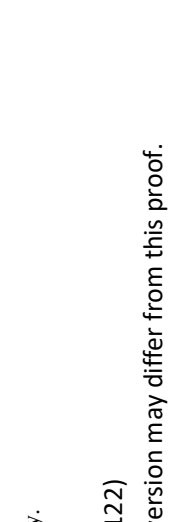 & & & & & Therapy & & $\begin{array}{l}\text { dose. } \\
\text { Control } \\
\text { group: } \\
\text { standard-of- } \\
\text { care } \\
\text { treatment }\end{array}$ \\
\hline 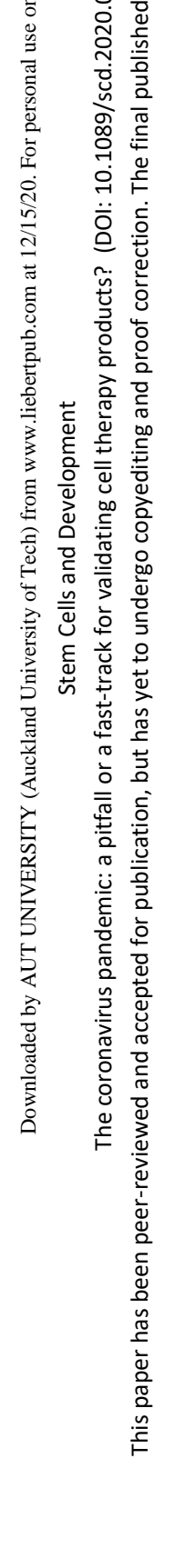 & 21 & $\begin{array}{l}\text { July-2020/ } \\
\text { December } \\
-2021\end{array}$ & $\begin{array}{c}\text { 2/ } \\
\text { randomize } \\
\text { d }\end{array}$ & $\begin{array}{l}\text { NCT0446609 } \\
\text { 8/ } \\
\text { University of } \\
\text { Minnesota, } \\
\text { Minneapolis, } \\
\text { Minnesota. }\end{array}$ & $\begin{array}{l}\text { Multi-center, } \\
\text { Randomized, } \\
\text { Placebo } \\
\text { Controlled, } \\
\text { Intervention } \\
\text { al Phase 2A } \\
\text { Clinical Trial } \\
\text { Evaluating } \\
\text { the Safety } \\
\text { and Potential } \\
\text { Efficacy of } \\
\text { Multiple } \\
\text { Dosing of } \\
\text { Mesenchyma } \\
\text { I Stromal } \\
\text { Cells in } \\
\text { Patients } \\
\text { With Severe } \\
\text { Acute } \\
\text { Respiratory } \\
\text { Syndrome } \\
\text { Coronavirus } \\
2 \text { (SARS-Cov- }\end{array}$ & $\begin{array}{c}\text { MSC } \\
\text { (unkown } \\
\text { source)/ } \\
300 \times 10^{\wedge} 6\end{array}$ & $\begin{array}{l}30 \\
\text { Experimental } \\
\text { group: } \\
\text { Three fixed } \\
\text { doses of } \\
\text { thawed MSC } \\
\text { approximately } \\
48 \text { hours } \\
\text { apart, } \\
\text { containing } \\
\text { DMSO } \\
\text { resuspended } \\
1: 1 \text { with } \\
\text { Dextran } 40+ \\
5 \% \text { human } \\
\text { serum } \\
\text { albumin [total } \\
\text { volume } 60 \\
\text { mL] } \\
\text { group: } \\
\text { Control } \\
\text { a }\end{array}$ \\
\hline
\end{tabular}


29

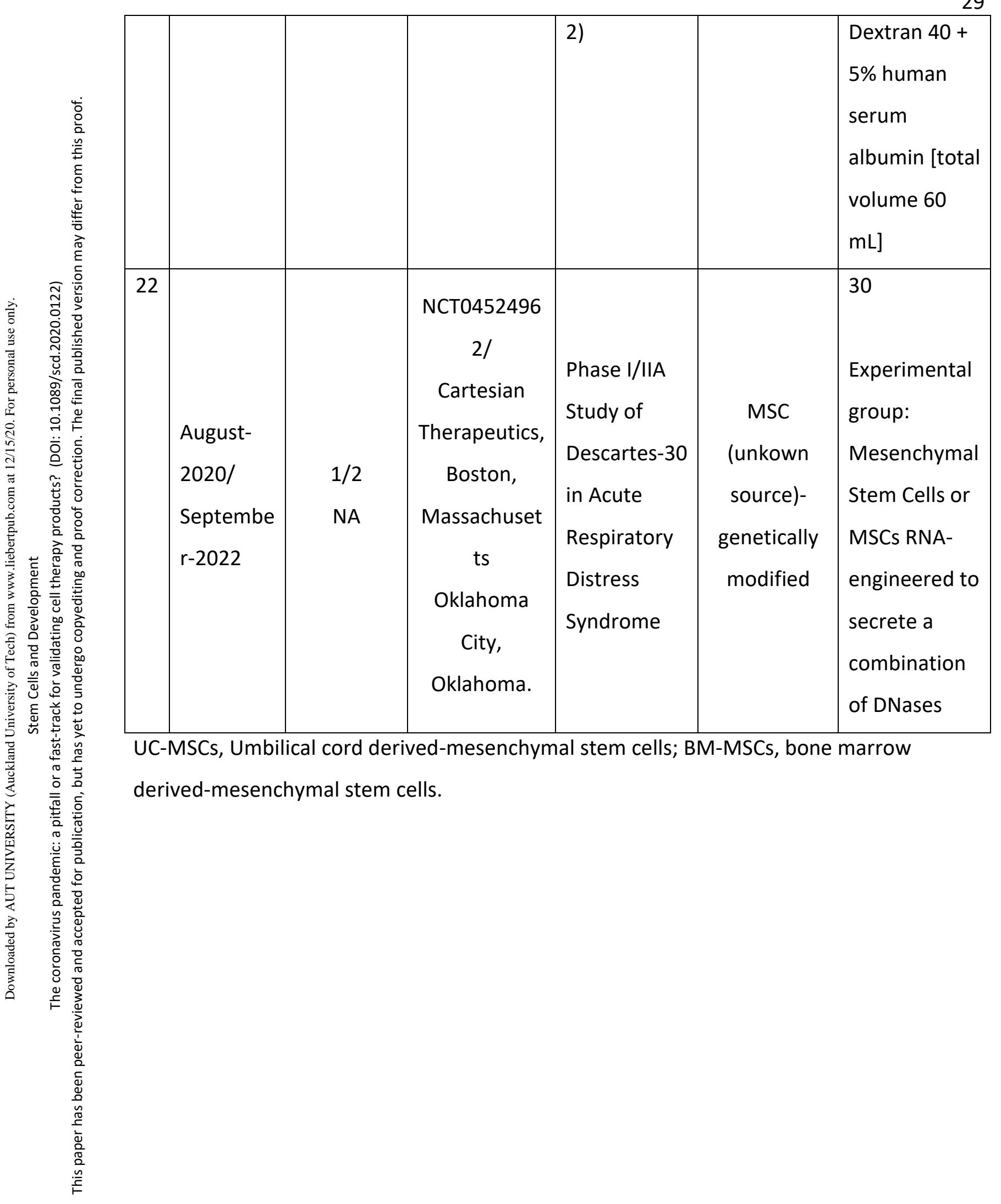


Page 30 of 30

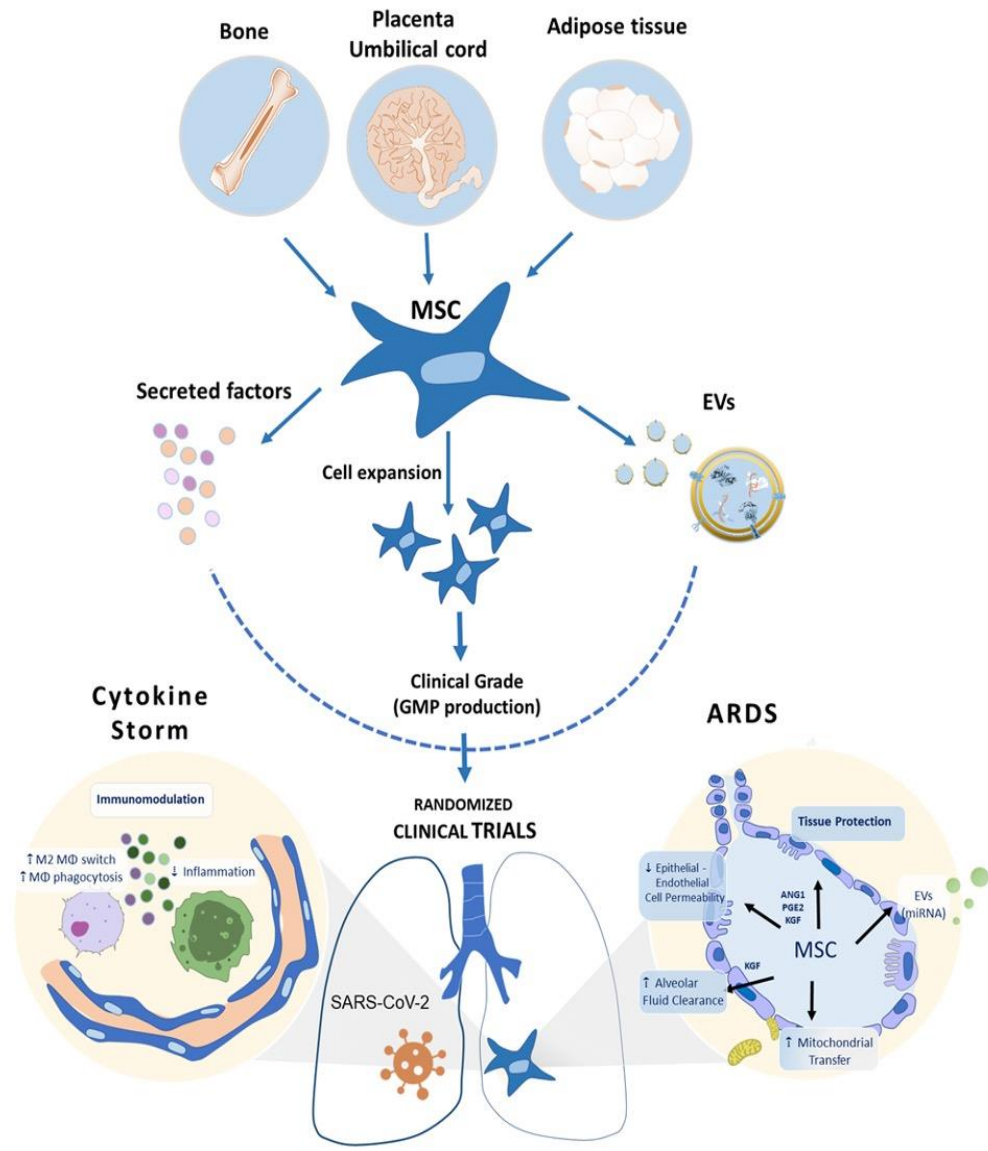

Figure 1: Overview of MSC properties relevant for potential use in COVID-19 related severe respiratory disease. 